Bilovodska, O., Golysheva, I., Gryshchenko, O., \& Strunz, H. (2017). Theoretical and practical fundamentals of scientific and educational projects: a case of Ukraine. Journal of International Studies, 10(2), 119-128. doi:10.14254/20718330.2017/10-2/8

\title{
Theoretical and practical fundamentals of scientific and educational projects: a case of Ukraine
}

\author{
Olena Bilovodska \\ Sumy State University, \\ Sumy, Ukraine \\ Email: bel@kmm.sumdu.edu.ua \\ Ievgeniia Golysheva \\ Sumy State University, \\ Sumy, Ukraine \\ Email:geo@kmm.sumdu.edu.ua
}

\section{Olena Gryshchenko}

Sumy State University,

Sumy, Ukraine

Email: efg@kmm.sumdu.edu.ua

\section{Herbert Strunz}

University A. Dubcek of Trencin,

Trencin, Slovakia

Email: Herbert.Strunz@fh-zwickau.de

Abstract. Development of educational and scientific spheres in general and project activity of universities in particular, acquire foreground importance in the modern world. In the article approaches to rendering a term "project" and its basic characteristics are analyzed. Scientific and educational projects are a special type: although they represent a subsidiary activity, they are vital to the image, rankings, prosperity and at some point to competitiveness. The major funding opportunities for scientific and educational projects are generalized. The authors have analyzed the official figures of the State Statistics Service of Ukraine which show the levels of cost funding of scientific and educational projects and describe its main sources in 2010-2015. A study of impact factors on the funding levels of Ukrainian scientific and educational projects by foreign sources was conducted using the method of correlation analysis. According to the results of the conducted analysis, it was determined that activity of international mobility of Ukrainian scientists doesn't influence the levels of international funding. It was also established that there is a strong inverse relationship between such factors as a share of expenditures on scientific and scientific-technical activities in GDP, a
Received:

November, 2016

1st Revision:

April, 2017

Accepted:

May, 2017

DOI:

$10.14254 / 2071$

$8330.2017 / 10-2 / 8$ 
number of organizations involved in scientific and scientific-technical activities and a number of grants for scientific research received from international funds.

Keywords: economic development, project, grant, project financing, correlation, funding opportunities.

JEL Classification: O22, I20, I23, I29

\section{INTRODUCTION.A PROJECT: DEFINITION AND CHARACTERISTICS}

Education is an intellectual resource for social modernization and also a lift for individually incoming social mobility. That is why development of educational and scientific spheres in general and project activity of universities in particular acquire foreground importance in the modern world. In this context it is necessary to consider the basic terms and correlations of project management. The term "project" comes from the Latin word "projectus" (which was formed from the words "pro" (forward) and "jacere" (to throw)) and means "to throw or cast forward". In general, project is an accurately stated piece of research (Webster's Seventh New Collegiate Dictionary, 1961, p. 681).

A Guide to the Project management Body Knowledge (PMBOK guide, 2004, 2013) provides two main ideas of any projects: non permanent (lasting for only a limited period of time with definite opening and closure date) and distinctive (the result of the project is unique or has some distinguishing attributes from the existing items).

There are different interpretations of the concept "project" in the modern literature and in the Internet. However, a big variety of approaches shows that the meaning of the terms is very similar. The classification is given in the table below (table 1).

Brandon (2006, p. 9) argues that any project has a list of the key characteristics: temporary endeavour with a beginning and an end; often broken into subprojects (or phases); creates a unique product or service; launched with a purpose; has interrelated activities (tasks); is an instrument of change.

Manning (2007) gives an interesting opinion to the key constituents of projects. There are tasks to be accomplished, time to inform about how fast, in which order and until when project tasks are to be accomplished, and teams. On the other hand, Gaupin, Knopfel, Morris, Motzel, and Pannenbacker (1999, p. 23) mention that project attributes are novelty, complexity, legal conditions, interdisciplinarity, and work distribution.

Thus, we can summarise that the term "project" can be characterized by a number of attributes. The most common are the following: focus on specific goals (specific outcomes), focus on novelty, coordinated execution of many interrelated activities, resources consumption, time limitations (the launch date, periods of interim reports, report deadlines, the completion date etc.).

The project exists exactly as long as it is required to obtain the final result. 
Generalization of rendering the term "project"

\begin{tabular}{|c|c|}
\hline Term's essence & Source \\
\hline \multicolumn{2}{|l|}{ The project as a process or activity } \\
\hline $\begin{array}{l}\text { Project is a sequence of activities which are connected, conducted over a limited period } \\
\text { of time, and targeted to generate a unique but well-defined outcome. }\end{array}$ & Baguley (2009) \\
\hline Project is a limited in time and resources purposeful action on the creation of something. & Funtov (2011, p. 25) \\
\hline $\begin{array}{l}\text { Project is a unique activity, which includes coordinated implementation of actions for } \\
\text { achieving certain goals within a limited period of time. }\end{array}$ & Kovalev (2003) \\
\hline Project is a temporary endeavour undertaken to create a unique product, service, or result. & $\begin{array}{l}\text { PMBOK guide (2004, } \\
\text { 2013) }\end{array}$ \\
\hline $\begin{array}{l}\text { Project is a unit, a complex of tasks and actions that have the following distinctive } \\
\text { features: clear goals, connection between goals and resources, specific start and end dates } \\
\text { of the project, a certain degree of novelty purposes and conditions of implementation, } \\
\text { inevitability of various conflicts within and around the project. }\end{array}$ & $\begin{array}{l}\text { Maliuk, \& Niemchin } \\
(2008 \text {, p. 220) }\end{array}$ \\
\hline $\begin{array}{l}\text { Project is an endeavour in which human, material and financial resources are organised } \\
\text { in a novel way, to undertake a unique scope of work, of given specification, within } \\
\text { constrains of cost and time, following a standard life cycle, so as to achieve beneficial } \\
\text { change defined by quantitative and qualitative objectives. }\end{array}$ & $\begin{array}{l}\text { Gaupin, Knopfel, Morris, } \\
\text { Motzel, \& Pannenbacker } \\
(1999, \text { p. } 90)\end{array}$ \\
\hline $\begin{array}{l}\text { ken to achieve planned objectives, which } \\
\text { or benefits. }\end{array}$ & $\begin{array}{l}\text { Association for Project } \\
\text { Management (2015) }\end{array}$ \\
\hline $\begin{array}{l}\text { Project is a unique process, consisting of a set of coordinated and controlled activities } \\
\text { with start and finish dates, undertaken to achieve an objective conforming to specific } \\
\text { requirements, including the constraints of time, cost and resources }\end{array}$ & $\begin{array}{l}\text { Bureau of Indian } \\
\text { Standards }(2003, \text { p. } 2)\end{array}$ \\
\hline \multicolumn{2}{|l|}{ The project as a set of activities } \\
\hline $\begin{array}{l}\text { Projec } \\
\text { with st }\end{array}$ & $\begin{array}{l}\text { The British Standard } \\
\text { Institution }(2012, \text { p. } 3)\end{array}$ \\
\hline $\begin{array}{l}\text { Project is an initial intent, image of the object } \\
\text { its description, schemes, drawings, calculatio }\end{array}$ & $\begin{array}{l}\text { Raizberg, \& Lozovskiy } \\
(2008, \text { p. 298) }\end{array}$ \\
\hline $\begin{array}{l}\text { Project is a unique set of co-ordinated activities, with defined starting and finishing points, } \\
\text { undertaken by an individual or organisation to meet specific objectives within a defined } \\
\text { schedule, cost and performance parameters. }\end{array}$ & $\begin{array}{l}\text { Gaupin, Knopfel, Morris, } \\
\text { Motzel, \& Pannenbacker } \\
(1999 \text {, p. } 90)\end{array}$ \\
\hline $\begin{array}{l}\text { Project is a complex of scientific, research, design, social, economic, managerial, business } \\
\text { and other components, connected by resources, performers and deadlines (designed and } \\
\text { aimed at changing an object of management). Using all these components in a group } \\
\text { helps to solve the problem more effectively and to reach a goal in a set period of time. }\end{array}$ & Tarasiuk, (2006, p. 10) \\
\hline \multicolumn{2}{|l|}{ The project as an undertaking } \\
\hline $\begin{array}{l}\text { undertaking to create a unique product or service with a defined start } \\
\text { pecific objectives that, when attained, signify completion. }\end{array}$ & Ward (2000, p. 163) \\
\hline $\begin{array}{l}\text { Project is an undertaking which is in principal characterised by its uniqueness of } \\
\text { conditions; e.g. as objectives, clear time, cost and quality and other conditions, } \\
\text { differentiation to other endeavours, project specific organisation }\end{array}$ & $\begin{array}{l}\text { Gaupin, Knopfel, Mor } \\
\text { Motzel, \& Pannenbac } \\
(1999 \text {, p. } 90)\end{array}$ \\
\hline
\end{tabular}

Source: Compiled based on content analysis: (Baguley, 2009; Funtov, 2011; Kovalev, 2003; PMBOK guide, 2004, 2013; Maliuk \& Niemchin, 2008; Gaupin, Knopfel, Morris, Motzel, \& Pannenbacker, 1999; Association for Project Management, 2015; Bureau of Indian Standards, 2003; The British Standard Institution, 2012; Raizberg, \& Lozovskiy, 2008; Tarasiuk, 2006; Ward, 2000)

\section{SCIENTIFIC OR EDUCATIONAL PROJECT}

Universities can provide projects that cover scientific and educational spheres individually or in combination. In general, these projects include fundamental research, scientific or social experiments, technological or social platforms, educational and social programs. Scientific and educational projects are a special type: although they represent a university's subsidiary activity, they are vital for the university's image, 
rankings, prosperity and at some point, for competitiveness. Figure 1 illustrates possible project deliverables that are intended to be supplied to a customer or society.

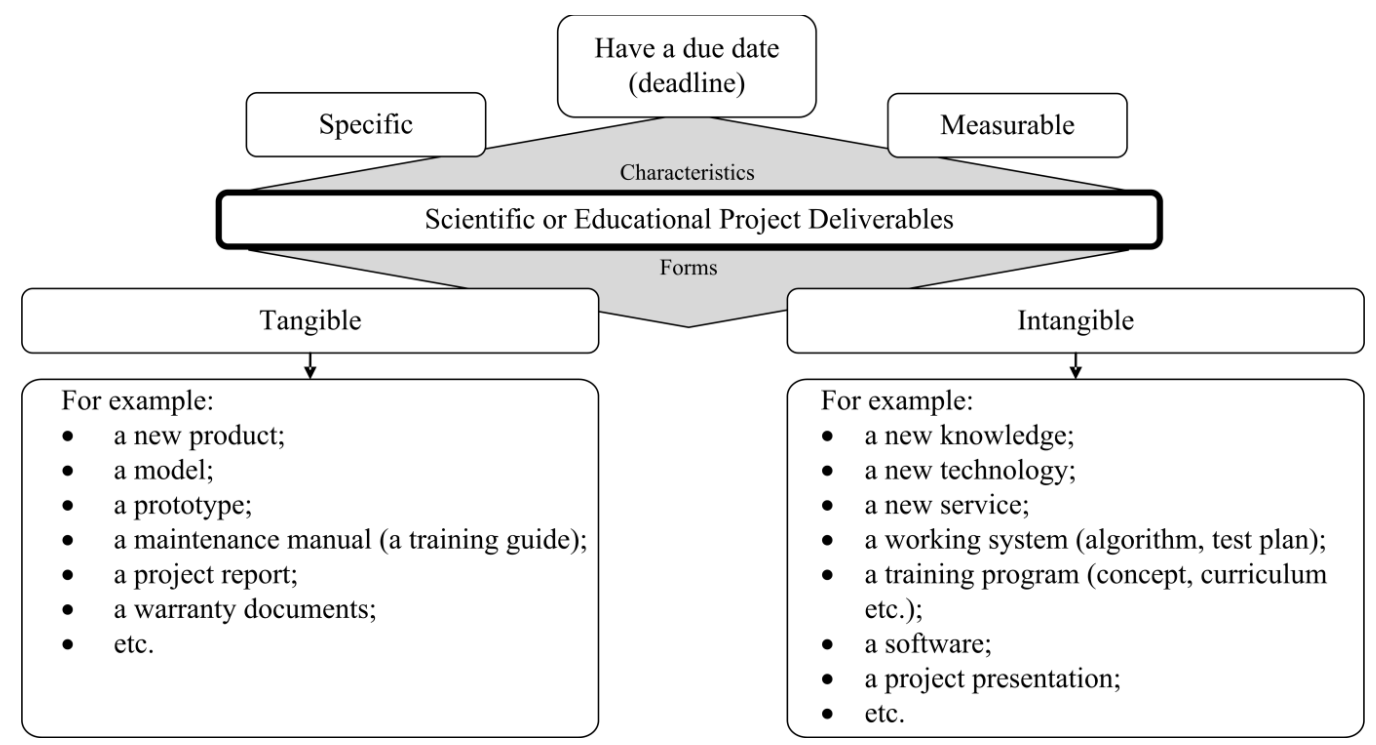

Figure 1. Scientific or educational project deliverables

Source: Own development

A wide range of funding opportunities exists to support programs and projects. The following sources are the most widespread in the scientific and educational sphere:

1. Granting is a support in a form of non-repayable funds given to launch and to develop specific project. Usually a grant maker defines the procedure submission process, and requires some level of compliance and reporting from a recipient. Usually (but not always) grant recipients are educational institutions, non-profit organizations, scientific institutions. For example, Horizon 2020, Erasmus+, European Regional Development Fund;

2. Awards and scholarships. It is a form of short-term academic financial aid (usually with a stipend) which is provided for researchers at all stages of their careers or scientific search. For example, Marie Skłodowska-Curie actions, Scholarship for Young Scientists Provided by the President of Ukraine;

3. State research and educational programs can be described as a funding for fundamental and applied research, extension and education to address certain social, economic or technological problem or scientific area. For example, The Agriculture and Food Research Initiative provided by US Department of Agriculture;

4. Sponsorship can be described as support of an event, project, person or organization financially or in a material form. Also sponsorship is a cash and/or in-kind fee paid to a project in return for access to the exploitable commercial potential associated with that project. For example, IBM Global Financing;

5. Business loan or bank loan. It is the reallocation of the assets for a certain period of time between the lender and the borrower at an interest rate, and evidenced by a note which specifies, among other things, the principal amount, interest rate, and date of repayment. 
According to the official figures of the State Statistics Service of Ukraine, there is an increase in funding levels of scientific and educational projects in 2010-2015. Shares of such sources as state budget, project executors' own funds and foreign sources in the total amount of funding can be seen on Figure 2.

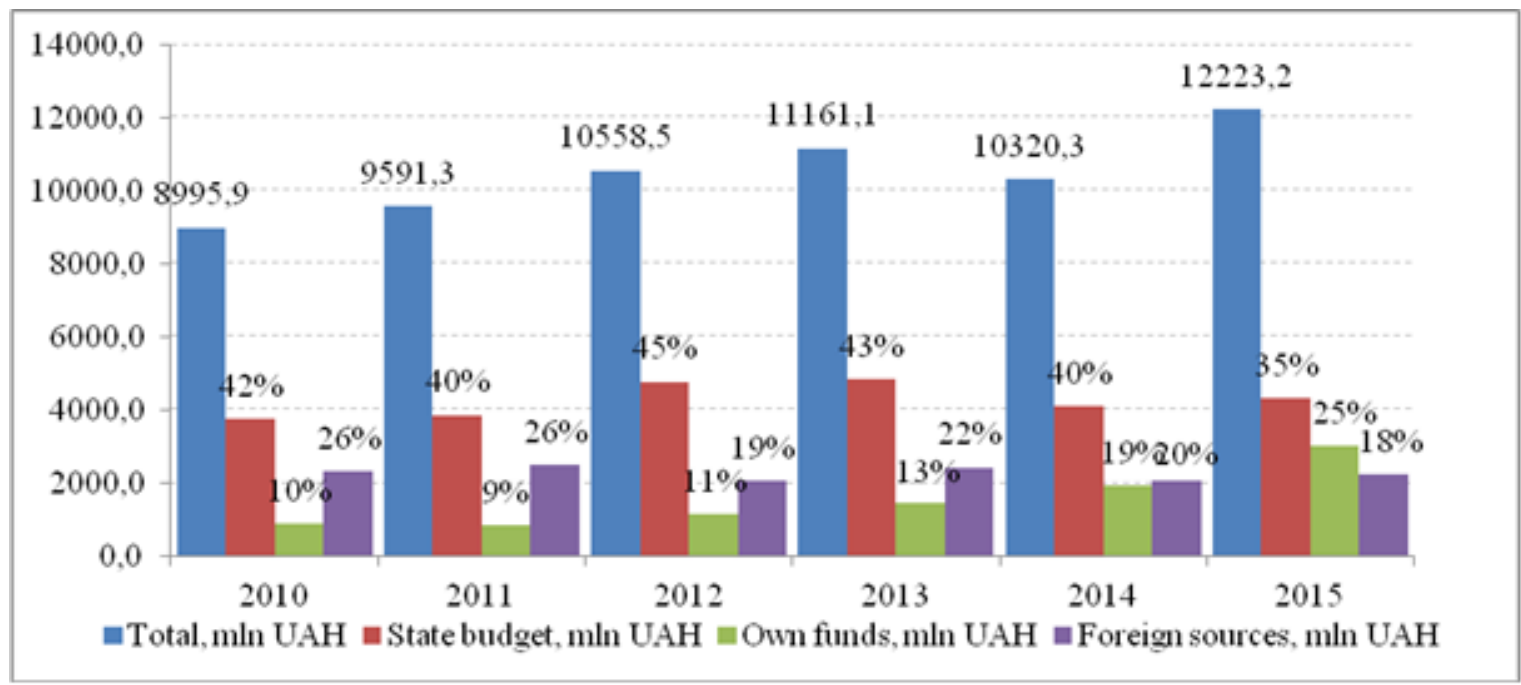

Figure 2. Funding levels of scientific and educational projects in 2010-2015

Source: Compiled based on State Statistics Service of Ukraine data

Analysis of Figure 2 shows that there is a decrease in the shares of state budget and foreign sources in the total amount of funding. Such changes happen due to increase in the shares of own funding and other financing sources (business sector, non-profit organizations, educational establishments, etc).

It should also be noted that state funding of scientific and educational projects in GDP is insignificant in comparison with EU countries. In 2014 the knowledge intensity of GDP of the closest European neighboring countries was higher than the Ukrainian one. For example, the knowledge intensity of GDP of Poland was $0,94 \%$, of Slovakia - 0,89\%, of Hungary - 1,37\%, of Bulgaria - $0,80 \%$. An average knowledge intensity of GDP in EU 28 amounts to 2,03\%.

\section{A STUDY OF IMPACT FACTORS ON THE FUNDING LEVELS OF UKRAINIAN SCIENTIFIC AND EDUCATIONAL PROJECTS BY FOREIGN SOURCES}

In order to conduct a research of impact factors on the funding levels of Ukrainian scientific and educational projects by foreign sources, the authors have put forward the following hypotheses:

1. The levels of foreign funding of scientific and educational projects are directly proportional to international mobility of Ukrainian scientists.

Travelling abroad for internship, studying and advanced professional training helps researchers gain experience which they can later use for development and implementation of scientific and educational projects. It also enhances integration of the Ukrainian science into international scientific and educational space. Adopting foreign experience makes is easier to form and send better applications for foreign funding of scientific and educational projects.

Direct participation in international conferences and workshops, teaching activities in foreign establishments improve the image of Ukrainian applicants, help to cooperate with foreign partners and discuss the key issues of joint applications. 
2. The levels of foreign funding of scientific and educational projects are directly proportional to government support of scientific activity.

The economic well-being of a country can be indicative of stability and reliability of cooperation with its representatives and of acceptable level of risk for foreign grantors.

If a country provides significant funding for the development of its own science and education, researches can be more competitive in their efforts to get international grants. It draws attention of foreign donors as a result.

3. The levels of foreign funding of scientific and educational projects are directly proportional to a number of organizations involved in scientific and educational activities.

The higher the number of organizations involved in scientific and educational activities, the more applications for foreign funding can be generated. It also increases project options for international donors.

A large number of scientific and educational organizations creates competitiveness inside the country and encourages continuous improvement and self-development.

A correlation analysis will be used in order to verify the hypotheses. The figures used for research are taken from the official website of the State Statistics Service of Ukraine.

As a resulting attribute $(\mathrm{Y})$ a number of grants received for scientific and educational projects from international funds in 2000-2015 (figure 3) has been chosen.

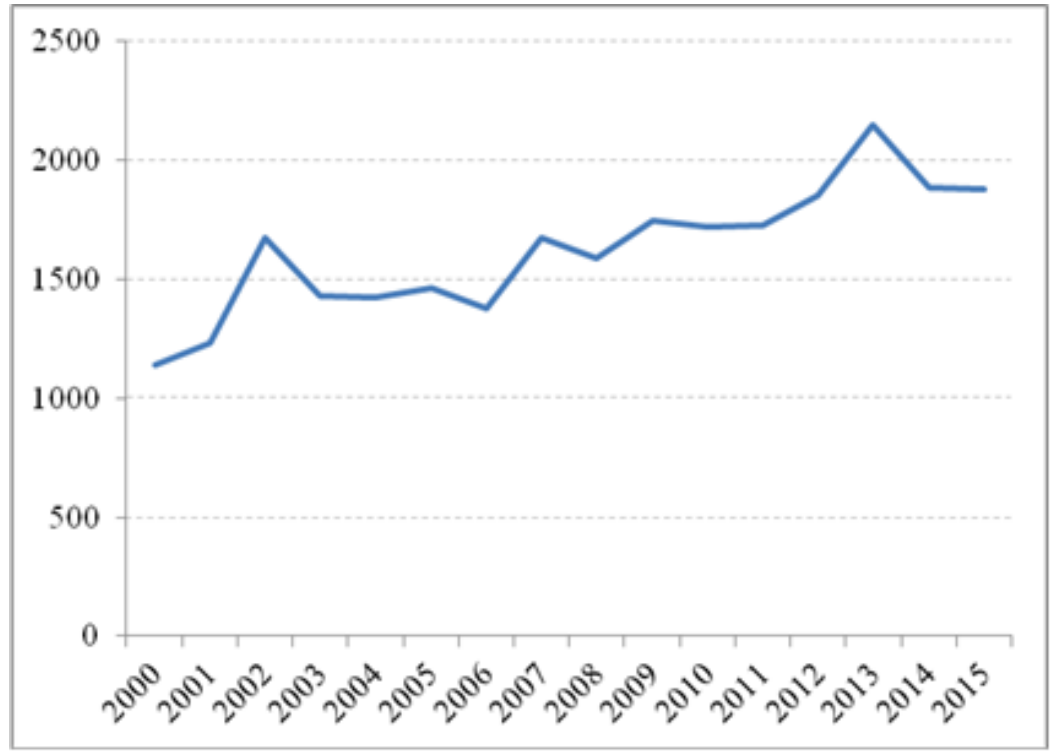

Figure 3. A number of grants for scientific research received from international funds in 2000-2015 Source: Compiled based on State Statistics Service of Ukraine data

According to the analysis results of Figure 3, during the researched period there has been a $65 \%$ increase in a number of received grants from 1138 in 2000 to 1882 in 2015 . At that an average annual growth rate of the number of grants was $4,1 \%$.

To verify the hypotheses the following factors have been chosen as impact factors on a resulting attribute (table 2):

- bypothesis 1: a number of researchers who travelled outside Ukraine for scientific or educational reasons;

- bypothesis 2: a share of expenditures on scientific and scientific-technical activities in GDP; 
- bypothesis 3: organizations involved in scientific and scientific-technical activities.

Table 2

Dynamics of impact factors in 2000-2015 for a research model construction

\begin{tabular}{|c|c|c|c|}
\hline Year & $\begin{array}{c}\text { A number of researchers who } \\
\text { travelled outside Ukraine for } \\
\text { scientific or educational } \\
\text { reasons, individuals }\left(\mathrm{X}_{1}\right)\end{array}$ & $\begin{array}{c}\text { A share of expenditures on } \\
\text { scientific and scientific- } \\
\text { technical activities in GDP, } \% \\
\left(\mathrm{X}_{2}\right)\end{array}$ & $\begin{array}{c}\text { Organizations involved in } \\
\text { scientific and scientific- } \\
\text { technical activities }\left(\mathrm{X}_{3}\right)\end{array}$ \\
\hline 2000 & 11430 & 0,96 & 1490 \\
\hline 2001 & 8639 & 0,98 & 1479 \\
\hline 2002 & 10641 & 0,95 & 1477 \\
\hline 2003 & 13190 & 1,06 & 1487 \\
\hline 2004 & 9063 & 1,03 & 1505 \\
\hline 2005 & 10115 & 0,99 & 1510 \\
\hline 2006 & 8922 & 0,92 & 1452 \\
\hline 2007 & 10983 & 0,86 & 13784 \\
\hline 2008 & 11288 & 0,84 & 1340 \\
\hline 2009 & 10442 & 0,86 & 1303 \\
\hline 2010 & 9898 & 0,83 & 1255 \\
\hline 2011 & 10264 & 0,74 & 1208 \\
\hline 2012 & 10453 & 0,75 & 1143 \\
\hline 2013 & 11060 & 0,7 & 999 \\
\hline 2014 & 7316 & 0,65 & 978 \\
\hline 2015 & 7077 & 0,62 & \\
\hline
\end{tabular}

Source: Compiled based on State Statistics Service of Ukraine data

A correlation matrix has been built with the help of MS Excel (Table 3) in order to verify the consistency of correlation between impact factors and resulting attribute.

Table 3

Matrix of pair correlation coefficients between impact factors and resulting attribute

\begin{tabular}{|c|c|c|c|c|}
\hline & $\boldsymbol{Y}$ & $\mathbf{X}_{\mathbf{1}}$ & $\mathbf{X}_{\mathbf{2}}$ & $\mathbf{X}_{\mathbf{3}}$ \\
\hline $\mathrm{Y}$ & 1 & & & \\
\hline $\mathrm{X}_{1}$ & $-0,16794$ & 1 & & \\
\hline $\mathrm{X}_{2}$ & $-0,81377$ & 0,458914 & 1 & 1 \\
\hline $\mathrm{X}_{3}$ & $-0,8008$ & 0,514231 & 0,958624 & \\
\hline
\end{tabular}

Source: Own calculations

The results of construction of the correlation matrix will be addressed separately for each hypothesis:

- bypothesis 1: given that the value of the pair correlation coefficient is $r_{\mathrm{yx} 1}=-0,16794$, the correlation between resulting attribute $\mathrm{Y}$ and impact factor and $\mathrm{X}_{1}$ is virtually non-existent. 
This makes it possible to conclude that activity of international mobility of Ukrainian scientists doesn't influence the levels of international funding. A reason for this can be that Ukrainian researchers do not make efficient use of opportunities given by the programs of international mobility. But at the same time, this can be explained by development of information and communication technologies which make it possible to establish and maintain relationships without direct encounter. A week correlation can be also attributed to a difficult economic situation in Ukraine and people's income level in different years, considering that in most cases international mobility requires investment of participants' own funds. That is why this hypothesis requires an in-depth analysis taking into account the reasons for travelling and determining the results of international visits. Unfortunately, such statistics aren't being kept on a national scale, and statistics at the level of a separate scientific or educational establishment can't give representative results;

- bypothesis 2: absolute value of the pair correlation coefficient is $\mathrm{r}_{\mathrm{yx} 2}-0,81377$ and it demonstrates a strong correlation between the resulting attribute $\mathrm{Y}$ and impact factor $\mathrm{X}_{2}$. Nevertheless, the hypothesis of a direct connection between the levels of foreign funding of scientific and educational projects and government support of scientific activity doesn't get substantiated. Analysis shows that reducing a share of expenditures on scientific and scientific-technical activities in GDP, increases, in fact, the number of grants received from international funds. Decline in government funding stimulates Ukrainian researchers to search for financing sources abroad. Such cuts in government funding give short-term cost savings, but can cause irreversible consequences in the long run:

- the brain drain of scientists abroad where the work of Ukrainian experts will be valued. It should be noted that a share of executors of scientific and educational projects in Ukraine has been steadily decreasing, and in 2014 it amounted to $0,5 \%$ of employed population. At the same time the equivalent figure for EU 28 amounted to 1,1\% in 2013;

- the problems that are relevant only for Ukrainian realities can stay outside the scope of the Ukrainian researchers' interests, since scientific and educational projects as part of international programs are directed mainly towards addressing the issues of international community;

- reduction of intellectual and tangible assets today can be difficult or impossible to recover in the future.

- bypothesis 3: analysis has also showed a strong correlation between the levels of foreign funding of scientific and educational projects and the number of organizations involved in scientific and scientifictechnical activities $\left(r_{y \times 3}=-0,8008\right)$. Nevertheless, the negative value of the pair correlation coefficient demonstrates an inverse relationship between the figures which disproves the hypothesis. In the authors' opinion, this can be explained by the natural selection in the difficult economic conditions, when weak scientific and educational establishments do not endure the fierce competition and are forced to cease their activities. It is possible that such a prospect is not a negative phenomenon, considering that budgetary and foreign funds won't be scattered, but will be accumulated for the implementation of ambitious and efficient projects.

It must be also noted that there is a significant directly proportional relationship between the levels of government funding and a number of organizations involved in scientific and educational activities. In the authors' opinion, reduction of such organizations is an obvious consequence of funding cuts (since the majority of scientific and educational establishments in Ukraine are state-owned). Such data only validates the conducted research. 


\section{SUMMARY AND CONCLUSIONS}

In this article are considered approach to defining a term 'project' and its key elements and practical aspects of projects financing in scientific and educational spheres. According to the results of the investigation the following authors' conclusions were introduced:

1) the deliverables of educational and scientific projects were detailed;

2) using the method of correlation analysis of the figures for the period 2000-2015, it was determined that activity of international mobility of Ukrainian scientists doesn't influence the levels of international funding;

3) the results of the conducted analysis have also showed that there is a strong inverse relationship between a number of grants for scientific research received from international funds and such factors as a share of expenditures on scientific and scientific-technical activities in GDP and a number of organizations involved in scientific and scientific-technical activities.

The results of the article may be a ground and a basis for project developers in education and science.

Taking into consideration the risks and high cost of projects, requirements of investors and project realization initiators to a data supply level of the business-planning process of projects constantly grow (Bogiv, 2012). It is important to mention that all the achievements point out the importance of further research and improvement of project management methods in various spheres. Further researches may also be aimed at levelling the risk assessment and the involvement of international partners in joint scientific and educational projects.

\section{REFERENCES}

Association for Project Management. (2015). What is project management? Retrieved April 7, 2016, from https://www.apm.org.uk/WhatIsPM.

Baguley, Ph. (2009). Instant Manager: Project Management. London: Hodder \& Stoughton Ltd.

Bogiv, Ya. S., Miroschenko, N. Yu., \& Pauk, O. Ye. (2012). Information support of enterprises' innovative projects business planning: composite elements and features of their interaction. Marketing and Management of Innovations, 4, 193-202. Retrieved April 7, 2016, from http://mmi.fem.sumdu.edu.ua/en/journals/2012/4/193-202.

Brandon, D. (2006). Project Management for Modern Information Systems. Hershey, PA: IRM Press.

Bureau of Indian Standards. (2003). IS / ISO 10006:2003 Quality Management Systems - Guidelines for Quality Management in Projects [MSD 2: Quality Management]. New Delhi: Bureau of Indian Standards.

Funtov, V. (2011). Osnovy upravleniia proektami v kompanii. Saint Petersburg: Piter.

Gaupin, G., Knopfel, H, Morris, P., Motzel, E., \& Pannenbacker, O. (1999). ICB - IPMA Competence Baseline. Version 2.0. Bremen: Eigenverlag.

Kovaliov, S. (2003). Proekty sovershenstovaniia i razvitiia deiatelnosti predpriiatiia - iniciaciia I panirovanie - shag za shagom. Konsultant directora, 21. Retrieved April 7, 2016, from http:/ /www.betec.ru/index.php?id=6\&sid=18.

Maliuk, V., \& Nemchyn, A. (2008). Proizvodstvennyi menedz̧ hment. Saint Petersburg: Piter.

Manning, S. (2008). Embedding projects in multiple contexts - a structuration perspective. International Journal of Project Management, 26, 30-37. doi:10.1016/j.ijproman.2007.08.012.

Official website of State Statistics Service of Ukraine. Retrieved May 13, 2017, from http://www.ukrstat.gov.ua.

Project Management Institute. (2004). A Guide to the Project Management Body of Knowledge (3rd ed.). Newtown Square, PA: Project Management Institute, Inc.

Project Management Institute. (2013). A Guide to the Project Management Body of Knowledge (5th ed.). Newtown Square, PA: Project Management Institute, Inc.

Raisberg, B., \& Lozovskii, L. (2008). Slovar soremenny ekonomicheskih terminov. Moscow: Airis-press.

Tarasiuk, G. (2006). Upravlinnia proektamy. Kyiv: Karavela. 
The British Standards Institution. (2012). BS ISO 21500:2012 Guidance on project management. Geneva: ISO copyright office.

Ward, J. L. (2000). Project Management Terms: A Working Glossary (2nd ed.). Arlington, VA: ESI International.

Webster's Seventh New Collegiate Dictionary based on Webster's Third New International Dictionary (1961). Springfield, MA: G. \& C. Merriam Company. 